\title{
Pelatihan Microsoft Office untuk Pengasuh Pondok Pesantren Nurul Ihsan Karangasem
}

\author{
${ }^{1 *}$ Affan Irfan Fauziawan, ${ }^{2}$ Indrianto, ${ }^{3}$ Suhana Sabdar \\ ${ }^{1,3}$ Program Studi Sistem Informasi, ${ }^{2}$ Program Studi Sistem Komputer ITB STIKOM Bali \\ *Email: fauziawan@yahoo.com
}

\begin{abstract}
ABSTRAK
Perkembangan teknologi telah banyak membantu pekerjaan manusia. Salah satu yang dapat kita nikmati dari perkembangan teknologi tersebut di antaranya yaitu Microsoft Word dan Microsoft Excel. Microsoft Word, berfungsi sebagai perangkat lunak pengolah kata meliputi membuat, mengedit, dan memformat dokumen. Microsoft Excel (Excel) merupakan program aplikasi spreadsheet (lembar kerja) yang bisa digunakan untuk membuat tabel dan menyajikan data dalam bentuk grafik. Pengasuh pondok pesantren Nurul Ihsan Karangasem, belum begitu mengerti dengan manfaat Microsoft Word dan Excel untuk membantu menyelesaikan pekerjaan sehari-hari. Metode yang digunakan pada kegiatan berupa sosialisasi dan pelatihan ini diikuti oleh para pengasuh/pendidik. Materi yang disampaikan terutama diberikan yang berhubungan dengan kegiatan yang ada di pondok pesantren, di antaranya absensi santri, pembukuan dan lain-lain. Para peserta sosialisasi sangat antusias mengikuti acara, dilanjutkan dengan sesi tanya jawab seputar manfaat Microsoft Word dan Excel. Kemudian dilanjutkan dengan pelatihan pemakaian Microsoft Word dan Excel yang dapat diaplikasikan langsung di pondok pesantren. Para pengasuh Pondok Pesantren Nurul Ihsan merasa senang dengan adanya kegiatan sosialisasi dan pelatihan ini. Adanya kegiatan pengabdian kepada masyarakat ini, sebagai ajang berbagi ilmu pemanfaatan Microsoft Word dan Excel untuk para pengasuh pondok pesantren dalam membantu pekerjaannya sehari-hari, sehingga dapat memanfaatkan kemajuan teknologi untuk selanjutnya mulai meninggalkan pembukuan secara manual.
\end{abstract}

Kata kunci : Pondok Pesantren, Microsoft Word, Pembukuan

\section{ABSTRACT}

Technological developments have helped a lot of human work. One of which we can enjoy from the development of these technologies include Microsoft Word and Microsoft Excel. Microsoft Word, functions as word processing software including creating, editing, and formatting documents. Microsoft Excel (Excel) is a spreadsheet application program (worksheets) that can be used to create tables and present data in graphical form. The guardians of the Islamic boarding school Nurul Ihsan Karangasem, do not really understand the benefits of Microsoft Word and Excel to help complete their daily work. The method used in the activity in the form of socialization and training for guardians/teachers. The material presented was mainly given in connection with activities in the Islamic boarding school, including the attendance of students, bookkeeping and others. The participants were very enthusiastic in the event, followed by a question and answer session about the benefits of 
Microsoft Word and Excel. Then proceed with training in using Microsoft Word and Excel which can be applied directly in Islamic boarding schools. The guardians at the Nurul Ihsan Islamic Boarding School were happy with the socialization and training activities. By conducting the community service activity, the team shares knowledge of using Microsoft Word and Excel for boarding school guardians, and helps them finishing daily works by utilizing the advantage of technology. They can start leaving manual-bookkeeping.

Key words: Islamic Boarding School, Microsoft Word, Bookkeeping

\section{PENDAHULUAN}

Perkembangan teknologi membuat meningkatnya penggunaan internet di Indonesia dan banyaknya efek negatif yang ditimbulkan. Oleh karenanya, Pemerintah Republik Indonesia melalui Kementerian Komunikasi dan Informatika (Kemkominfo) yang membidangi urusan komunikasi dan informatika membuat suatu program yang memiliki tujuan untuk memberikan pemahaman kepada masyarakat bagaimana menggunakan internet secara baik dan bijak dalam program internet sehat dan aman (INSAN). (Astuti, 2016) Meningkatnya perkembangan teknologi informasi harus diiringi dengan pengenalan dan pembelajaran komputer sejak dini. (Nugroho, 2010). Pemanfaatan teknologi dan informasi merupakan salah satu upaya untuk mengeliminasi keterbatasan yang dimiliki oleh masyarakat. Salah satu pemanfaatan perkembangan teknologi yaitu dengan semakin terbantunya manusia dalam mengerjakan pekerjaan sehari-hari. (Ritchi, 2018). Pondok Pesantren Nurul Ihsan terletak di Banjar Ujung Pesisi, Desa Tumbu Kabupaten Karangasem belum banyak memanfaatkan kemajuan teknologi. Lingkungan sekitar pondok pesantren ini berada di pesisir pantai Ujung, bagian timur dari pulau Bali. Pondok pesantren ini dikelola swadaya oleh masyarakat sekitar, hanya mengandalkan keikhlasan dan kesukarelaan masyarakat sekitar, yang kebanyakan berprofesi sebagai nelayan dalam menjalankan kegiatannya. Di pondok pesantren ini untuk pembukuan dan kegiatan sehari-hari masih menggunakan tulisan manual. Oleh karena itu pada pengabdian kepada masyarakat ini akan ditekankan kepada pengenalan komputer dan kegiatan selanjutnya yaitu pelatihan tentang Microsoft Word dan Microsoft Excel untuk para pengasuh pondok pesantren Nurul Ihsan, Karangasem. Penggunaan teknologi dalam penyampaian informasi memiliki peran yang sangat penting bagi setiap instansi. (Priyadi, 2018). Persoalan yang muncul dari hasil diskusi dengan pondok pesantren digambarkan pada tabel berikut.

Tabel 1 Analisis Situasi

\begin{tabular}{|c|l|l|l|}
\hline No & Bidang & Permasalahan & Solusi \\
\hline 1 & $\begin{array}{l}\text { Pendidikan } \\
\text { Keagamaan }\end{array}$ & $\begin{array}{l}\text { Belum mengenal } \\
\text { Microsoft Word }\end{array}$ & Pelatihan \\
\hline 2 & $\begin{array}{l}\text { Pendidikan } \\
\text { Keagamaan }\end{array}$ & $\begin{array}{c}\text { Belum mengenal } \\
\text { Microsoft Excel }\end{array}$ & Pelatihan \\
\hline
\end{tabular}

Faktor terpenting guna mengimplementasikan teknologi komputer adalah sumber daya manusia sebagai pengguna dari sitem komputer tersebut. (Sulistyanto, 2017).

\section{RUMUSAN MASALAH}

Berdasarkan wawancara yang dilakukan kepada pengasuh yang ada di pondok pesantren Nurul Ihsan, 
Karangasem diperoleh informasi bahwa sebagian besar belum banyak mengerti tentang perkembangan ilmu di bidang TIK (teknologi informasi dan komunikasi). Beberapa permasalahan mitra di antaranya adalah para pengasuh masih menggunakan cara manual untuk pembukuan, absensi dan lainnya. Oleh karena itu, kegiatan pengabdian masyarakat ini adalah pelatihan tentang Microsoft Office (Word dan Excel) untuk para pengasuh pondok pesantren, yang berkaitan dengan pembukuan dan absensi kelas. Menurut Ikhwani (2015), Microsoft Word menjadi program pengolah kata yang handal dan paling banyak digunakan oleh pengguna komputer.

\section{METODE}

Metode yang digunakan pada kegiatan pengabdian kepada masyarakat ini yaitu dengan menggunakan metode pelatihan. Kegiatan ini dibagi ke dalam beberapa tahap, yakni tahap persiapan, tahap perencanaan, tahap pelaksanaan dan tahap pelatihan. Setelah diberikan sosialisasi tentang komputer, pada kegiatan selanjutnya diberikan kesempatan kepada para pengasuh pondok pesantren untuk mempelajari tentang Microsoft Word dan Microsoft Excel yang berguna untuk kegiatan sehari-hari seperti absensi, pembukuan dan lain-lain. Para pengasuh pondok pesantren melakukan praktik langsung dalam mengoperasikan Microsoft Word dan Microsoft Excel. Alur kerja dari kegiatan pelatihan adalah sebagai berikut:

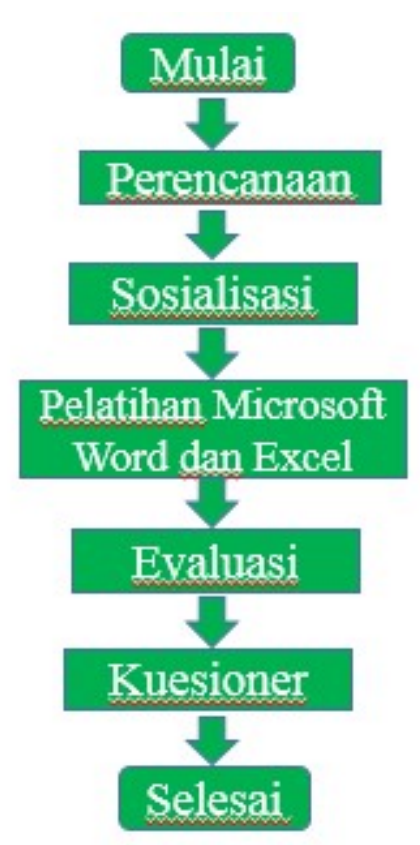

Gambar. 1 Alur Kerja Kegiatan

\section{PEMBAHASAN}

Kegiatan pengabdian kepada masyarakat berupa sosialisasi dan pelatihan tentang Microsoft Word dan Excel untuk para guru/pengasuh pondok pesantren telah selesai dilaksanakan. Pelatihan yang diberikan berkaitan dengan kegiatan sehari-hari di pondok pesantren di antaranya yaitu pembuatan absensi kelas, pembukuan, dan lain-lain.

Materi yang diberikan yaitu tentang Microsoft Office, terutama tentang Microsoft Word dan Excel. Materi berupa presentasi dan juga modul pelatihan yang dibagikan, yaitu tentang:

1. Pengenalan Komputer

2. Manfaat Komputer

3. Pengenalan Microsoft Office

4. Pengenalan Microsoft Word

5. Pengenalan Microsoft Excel

6. Dan lain-lain 
Saat pemaparan awal masih banyak para pengasuh dan murid pondok pesantren Nurul Ihsan yang belum mengetahui tentang komputer. Selama ini untuk kegiatan absensi, pembukuan masih menggunakan sistem manual, yaitu mencatat di buku/kertas, sehingga pada saat presentasi pengenalan tentang komputer lebih dispesifikkan lagi yaitu mengenalkan Microsoft Office (Microsoft Word dan Excel) dengan harapan dapat diaplikasikan langsung dalam kegiatan sehari-hari.

Setelah selesai presentasi, kemudian dilanjutkan dengan sesi tanya jawab. Beberapa pertanyaan yang muncul pada kegiatan sosialisasi di antaranya adalah:

1. Bagaimana cara mengoperasikan komputer yang baik dan benar?

2. Bagaimana cara untuk membuat tabel di Microsoft Excel?

3. Apa saja yang bisa dilakukan untuk membantu pembukuan dan absensi di pondok pesantren?

4. Bagaimanakah cara agar cepat mempelajari Microsoft Word dan Excel?

5. Dan lain-lain.

Pertanyaan tersebut dinilai cukup kritis untuk para pengasuh dari sebuah pondok pesantren yang masih konvensional. Sesi selanjutnya adalah penjelasan dan diskusi disertai contohcontoh yang mudah dimengerti oleh para peserta sosialisasi. Contoh-contoh disertai dengan penjelasan yang mudah, yang terjadi di kehidupan sehari-hari, membuat para peserta mudah memahami materi sosialisasi yang dibawakan. Berikutnya sesi penerapan materi dengan latihan menggunakan aplikasi Microsoft Word dan Excel yang berhubungan dengan kegiatan di pondok pesantren. Setelah sesi latihan ini selesai, materi lainnya dilanjutkan pada hari-hari berikutnya dengan pendampingan belajar mandiri.

Dokumentasi dalam kegiatan sosialisasi tentang pengenalan komputer, Microsoft Office, Microsoft Word, Excel, dan lain-lain seperti gambar di bawah ini:

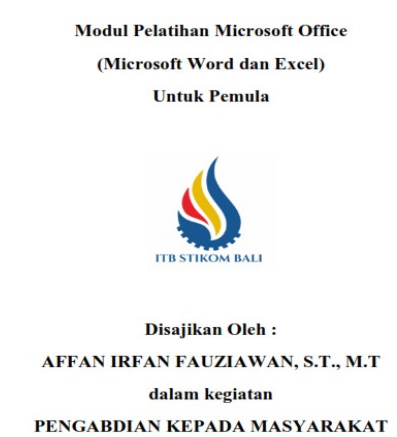

Gambar. 2 Modul Pelatihan Microsoft Office

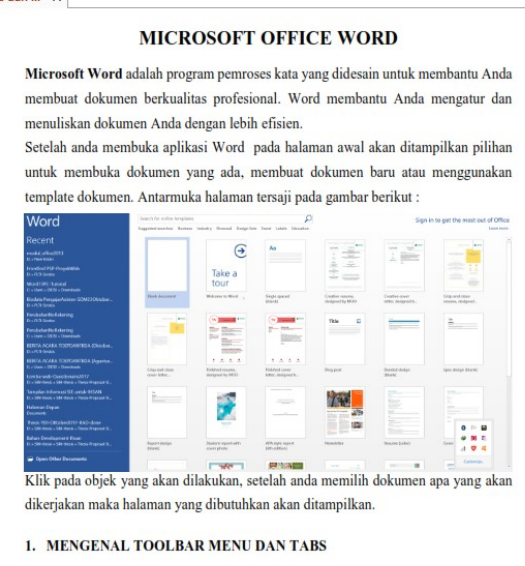

Gambar. 3 Materi Tentang Microsoft Word 


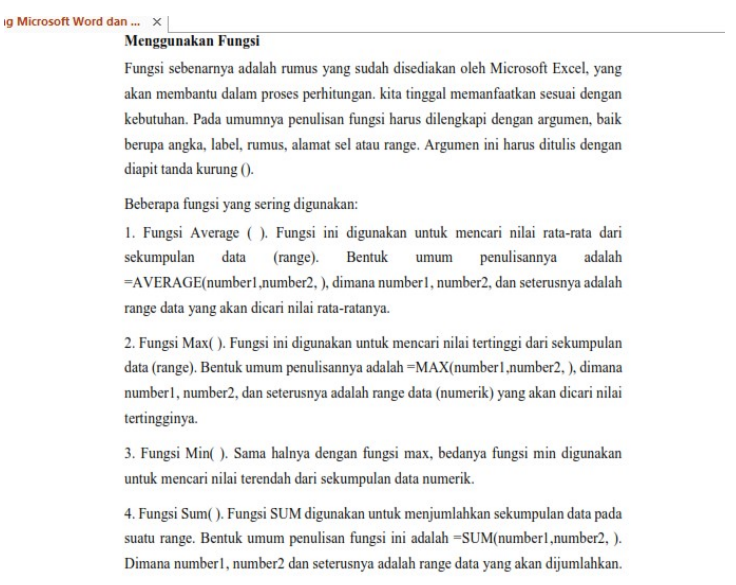

Gambar. 4 Materi Tentang Microsoft Excel

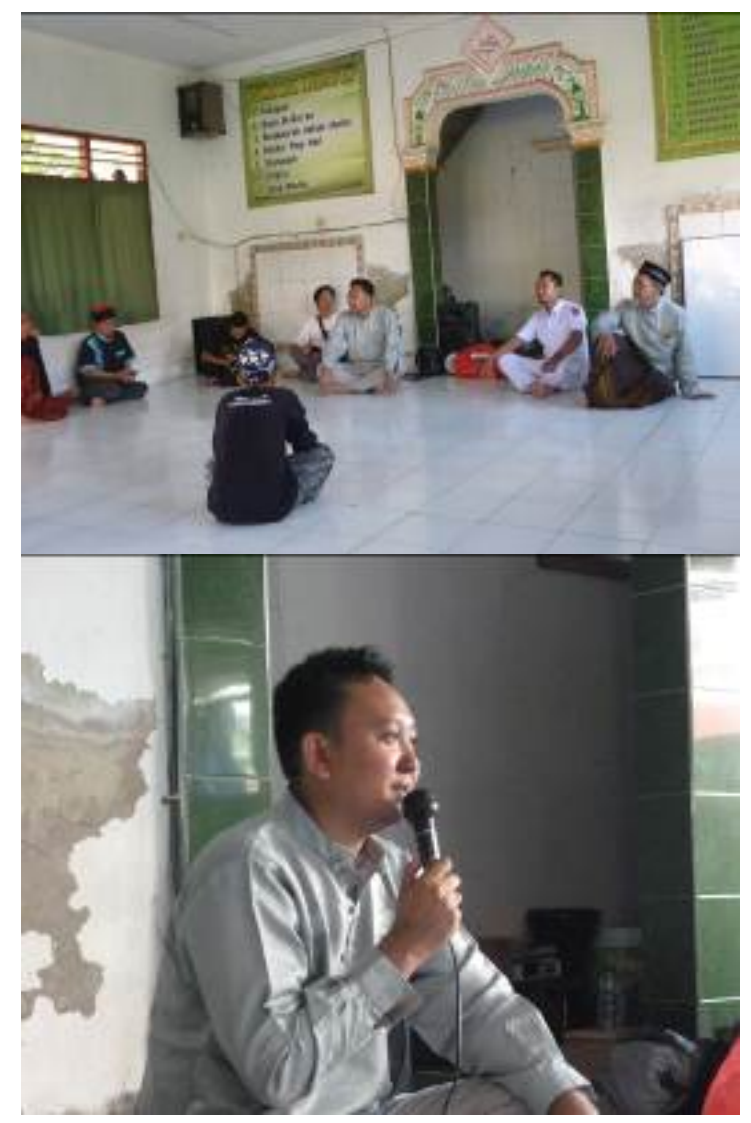

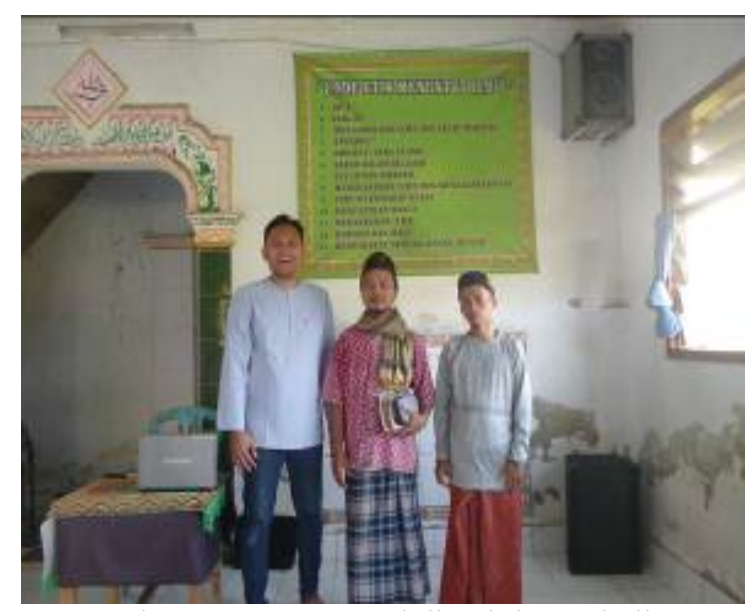

Gambar. 5 Suasana Sosialisasi dan Pelatihan

\section{SIMPULAN}

Kegiatan pengabdian pada masyarakat di Pondok Pesantren Nurul Ihsan, Banjar Dinas Ujung Pesisi, Karangasem telah berjalan dengan baik, materi sosialisasi dan pelatihan yang diberikan yaitu tentang Microsoft Office, khususnya Microsoft Word dan Microsoft Excel. Peserta sosialisasi dan pelatihan ini adalah pengasuh/guru di Pondok Pesantren. Rangkaian acara meliputi: sosialisasi, dilanjutkan dengan praktek langsung penggunaan aplikasi Microsoft Word dan Microsoft Excel untuk kebutuhan di Pondok Pesantren, antara lain membuat daftar absensi santri, membuat pembukuan pondok pesantren, dan lain-lain. Adanya praktek langsung tentang Microsoft Word dan Microsoft Excel membuat peserta pelatihan menjadi lebih paham dan mengerti fungsi dari aplikasi tersebut. Di sela-sela sosialisasi dan pelatihan, juga diadakan tanya jawab. Hasil akhir sesi tanya jawab tersebut adalah bahwa peserta menjadi lebih tahu fungsi dan kegunaan aplikasi Microsoft Word dan Microsoft Excel terutama untuk kebutuhan di Pondok Pesantren dan lingkungan sekitarnya. Sebagai evaluasi, di akhir kegiatan diberikan kuesioner tentang pelaksanaan 
kegiatan sosialisasi dan pelatihan Microsoft Word dan Excel. Dari 10 pengasuh sebagai responden, hampir 95\% para peserta senang mengikuti kegiatan ini, dan mendapatkan pengetahuan baru. Sebagian besar ( $>95 \%$ ) para pengasuh juga semakin paham dan dapat mengoperasikan aplikasi Microsoft Word dan Excel untuk kegiatan sehari-hari di pondok pesantren.

\section{UCAPAN TERIMA KASIH}

Ucapan terima kasih penulis sampaikan kepada Pondok Pesantren Nurul Ihsan di Banjar Dinas Ujung Pesisi, Desa Tumbu, Karangasem, sebagai mitra pengabdian kepada masyarakat ini, serta kepada ITB STIKOM Bali yang telah mendukung dan memberikan dana untuk menjalankan kegiatan ini, sehingga kegiatan dapat berjalan dengan baik dan lancar.

\section{DAFTAR PUSTAKA}

Astuti, S.D., Putri, I.P., Ali, D.S. (2016). Strategi Komunikasi Program Internet Sehat dan Aman Kementerian Komunikasi Dan Informatika Republik Indonesia. Jurnal Komunikasi, Vol. 8, No. 1. 25-35.

Nugroho, M.S.P., Setyowati. S., Sudjatmiko. A., \& Fadilah. U. (2010). Bantuan Komputer dan Pelatihan Program Microsoft Word Bagi Guru dan Murid Madrasah Ibtidaiyah Muhammadiyah di Sukaharjo dan Boyolali. Warta LPM, Vol. 13 No. 1, 20-27.

Direktorat Integrasi Data dan Sistem Informasi IPB. (2017). Panduan Teknis Microsoft Word 2013. Modul Teknis.

Ritchi, H., Zulkarnaen, R.M., Dewantara, Z., \& Prayogi, Y. (2018). Pemanfaatan Teknologi Informasi Dalam Upaya Peningkatan Aksesibilitas UKM (Desa
Wisata) Kepada Pasar di Lokasi Wisata Pangandaran dan Sekitarnya. Jurnal Pengabdian Kepada Masyarakat, Vol. 2 No. 1. 36-40.

Priyadi, D.A., Lestari, E.W., (2018). Perancangan Sistem Informasi Surat Menyurat Pada Kantor Desa Tanjungsari Kutowinangun Kebumen Berbasis Desktop. Jurnal Teknik Komputer, Volume 4 (2). 84-91.

Sulistyanto, H. (2017). Pakom Pelatihan Pengoperasian Komputer Bagi Perangkat Desa di Kecamatan Gondangrejo Kabupaten Karanganyar. Warta LPM, Vol. 20 No. 2, 111-114.

Ikhwani, Y., Budiman, H., Hadi, S., (2015). Pelatihan Aplikasi Microsoft Word 2013 pada SMP H.A Johansyah A Banjarmasin. Jurnal Al-Ikhlas. Vol. 1. 1114.

Noviandri, H., Sarwandi. (2017). Microsoft Office 2016 untuk Pemula. Jakarta : Elex Komputindo. pp : 85-95. 